\title{
PENGARUH INOKULASI MIKORIZA ARBUSKULAR TERHADAP PERTUMBUHAN BIBIT DAN INTENSITAS PENYAKIT BERCAK DAUN CENGKEH
}

\section{The effect of arbuscular mycorrhiza inoculation on the growth of clove seedling and leaf spot} intensity

\author{
Ayu Octavia Tanjung Putri ${ }^{1}$, Bambang Hadisutrisno ${ }^{2}$ dan Arif Wibowo ${ }^{2}$ \\ ${ }^{1}$ Program Studi Fitopatologi, Fakultas Pertanian, Universitas Gadjah Mada \\ email: ayu_ooocta@yahoo.co.id \\ ${ }^{2}$ Departemen Hama dan Penyakit Tumbuhan, Fakultas Pertanian, Universitas Gadjah Mada \\ Jalan Flora, Bulak Sumur, Yogyakarta, Indonesia
}

Tanggal diterima: 27 Juni 2016, Tanggal direvisi: 29 Juli 2016, Disetujui terbit: 15 Desember 2016

\begin{abstract}
The potential of arbuscular mycorrhiza fungi on the growth of clove seedling and leaf spot intensity. This researches aims to assess the ability of arbuscular mycorrhiza (AM) fungi in growth and suppress the intensity of leaf spot disease on clove seeds. The experiment was arraged in completely randomized design (CRD) $2 \times 2$ factorial. The treatments examined were: without mycorrhiza and compost $\left(M_{0} P_{0}\right)$, without mycorrhiza and with compost $\left(M_{0} P_{1}\right)$, with mycorrhiza and without compost $\left(M_{1} P_{0}\right)$, and with mycorrhiza and compost $\left(M_{1} P_{1}\right)$. The observed variables were the clove seedlings height, leaf numbers, symptom and intensity of leaf spot disease, and detection of salicylic acid (SA) with thin layer chromatography (TLC). The result showed that aplication of AM Fungi $\left(M_{1}\right)$ to clove seedlings support clove growth and dicreased intensity of leaf spot disease, but there was no interaction between mycorrhiza and composting in all observation variables. Salicylic acid contained in all treatment were tested.
\end{abstract}

Keywords: biological controls, AM Fungi, clove, leaf spot

\begin{abstract}
ABSTRAK
Pengaruh inokulasi mikoriza arbuskular terhadap pertumbuhan bibit dan intensitas penyakit bercak daun cengkeh. Penelitian ini bertujuan untuk mengkaji kemampuan jamur mikoriza arbuskular (JMA) dalam peningkatan pertumbuhan dan menekan intensitas penyakit bercak daun pada bibit cengkeh. Penelitian disusun dalam Rancangan Acak Lengkap (RAL) 2 × 2 faktorial dengan perlakuan yang diujikan yaitu tanaman tidak diinokulasi jamur mikoriza dan tidak diberi kompos $\left(\mathrm{M}_{0} \mathrm{P}_{0}\right)$, tanaman tanpa diinokulasi jamur mikoriza dengan pemberian kompos $\left(\mathrm{M}_{0} \mathrm{P}_{1}\right)$, tanaman yang diinokulasi jamur mikoriza tanpa pemberian kompos $\left(\mathrm{M}_{1} \mathrm{P}_{0}\right)$, dan tanaman yang diinokulasi jamur mikoriza dengan pemberian kompos $\left(\mathrm{M}_{1} \mathrm{P}_{1}\right)$. Parameter yang diamati meliputi tinggi tanaman, jumlah daun, intensitas penyakit bercak daun, dan deteksi asam salisilat dengan metode Kromatografi Lapis Tipis (KLT). Hasil penelitian menunjukkan bahwa tidak terdapat interaksi antara pemberian JMA dengan kompos disemua variabel pengamatan. Namun, pemberian JMA $\left(\mathbf{M}_{1}\right)$ mampu mendukung pertumbuhan bibit cengkeh dan menekan intensitas penyakit bercak daun cengkeh. Respon ketahanan tanaman berupa asam salisilat terdapat di setiap perlakuan yang diuji.
\end{abstract}

Kata kunci: pengendalian biologi, JMA, cengkeh, bercak daun

\section{PENDAHULUAN}

Cengkeh (Syzygium aromaticum (L.) Merr. \& Perr) memiliki peran yang besar dalam penyediaan bahan baku industri rokok kretek dan perdagangan (Dirjenbun, 2012). Cengkeh sendiri merupakan tanaman rempah-rempah unggulan asli Indonesia yang sejak dulu menjadi salah satu komoditi utama sektor perkebunan (Shofiana, Sulistyowati, \& Muhibuddin, 2015). Selama periode tahun 2008 hingga tahun 2013, produktivitas cengkeh sangat fluktuatif dan cenderung mengalami peningkatan, namun peningkatan luas pertanaman dan produksi cengkeh dirasa masih sangat kurang untuk memenuhi kebutuhan cengkeh baik skala domestik maupun internasional (Direktorat Jenderal Perkebunan, 2016).

Meningkatnya area pertanaman cengkeh ternyata diikuti juga oleh peningkatan 
permasalahan di lapangan. Beberapa penyakit berkembang secara epidemik dan menimbulkan kerugian yang besar (Semangun, 2000). Kondisi di lapangan menunjukkan bahwa banyak tanaman cengkeh yang sudah tua dan rusak, karena serangan hama dan penyakit, kurang pemeliharaan atau karena belum menggunakan bibit unggul (Dirjenbun, 2012). Salah satu faktor penentu dalam pengendalian penyakit adalah penggunaan bibit unggul yang memiliki kualitas dan kuantitas yang baik. Penggunaan agens pengendali hayati yang membentuk simbiosis mutualisme pada tanaman inangnya dapat dijadikan sebagai salah satu upaya untuk mendapatkan bibit cengkeh yang berkualitas.

Mikoriza merupakan salah satu bentuk simbiosis mutualisme antara jamur dan sistem akar tanaman tingkat tinggi. Jamur mikoriza arbuskular (JMA) sendiri merupakan salah satu kelompok jamur tanah biotrof obligat yang tidak dapat tumbuh bila terpisah dari tanaman inang (Balai Besar Litbang Sumberdaya Lahan Pertanian, 2006) dan termasuk agens pengendali hayati yang cukup potensial. JMA menginfeksi sistem perakaran tanaman inang, membentuk jalinan hifa secara intensif sehingga tanaman yang bermikoriza tersebut mampu meningkatkan kapasitas dalam penyerapan hara dan air (Rungkat, 2009 dalam Muis, Indradewa, \& Widada, 2013). Selain berperan dalam pertumbuhan, JMA juga dilaporkan dapat menjadi agens pengendalian hayati (Biological Control) yang potensial (Suharti, Habazar, Nasir, Dachryanus, \& Jamsari, 2011). Inokulasi JMA pada fase pembibitan akan menghasilkan simbiosis yang lebih baik antara tanaman dengan JMA.

Penelitian pemanfaatan JMA pada bibit tanaman perkebunan selain cengkeh telah banyak dilakukan. Hasil penelitian Sariasih et al. (2012) menunjukkan bahwa bibit kakao yang diinokulasi dengan JMA mampu meningkatkan tinggi tanaman dan jumlah daun dibandingkan dengan bibit tanpa inokulasi. Selain itu, inokulasi JMA pada bibit lada diketahui menghasilkan jumlah daun lebih banyak dibandingkan dengan bibit tanpa diinokulasi (Hasid \& Halim, 2011), inokulasi JMA pada stek bibit lada juga meningkatkan panjang batang, jumlah akar, dan mempersingkat masa pembibitan (Aguzaen, 2009). Namun kajian mengenai pengaruh JMA pada pertumbuhan dan kesehatan pada bibit cengkeh masih belum banyak dilakukan. Mengingat bahwa cengkeh memiliki nilai ekonomi yang cukup tinggi, maka perlu dikaji mengenai kemampuan JMA dalam peningkatan pertumbuhan dan menekan intensitas penyakit bercak daun pada bibit cengkeh.

\section{BAHAN DAN METODE}

\section{A. Tempat dan waktu penelitian}

Penelitian dilaksanakan mulai bulan Mei 2015 sampai akhir April 2016 di Laboratoium Mikologi Pertanian, Fakultas Pertanian UGM, dan pembibitan dilakukan di rumah plastik Condongcatur dan Kebun Percobaan Banguntapan (113 m dpl), Yogyakarta.

\section{B. Pelaksanaan penelitian}

Penelitian disusun dalam Rancangan Acak Lengkap (RAL) faktorial dengan menggunakan dua faktor, meliputi faktor pertama adalah tidak diinokulasi JMA $\left(\mathrm{M}_{0}\right)$ dan diinokulasi JMA 30g/tanaman $\left(\mathrm{M}_{1}\right)$, faktor kedua adalah tanpa kompos $\left(\mathrm{P}_{0}\right)$ dan dengan kompos $\left(\mathrm{P}_{1}\right)$ perbandingan $1: 1$ dengan tanah steril. Dengan demikian diperoleh 4 kombinasi perlakuan dengan 5 ulangan, masing-masing unit percobaan terdiri dari 7 tanaman sehingga diperoleh 140 unit percobaan.

\section{Persiapan medium tanam}

Bibit cengkeh yang digunakan adalah bibit cengkeh Zanzibar berumur 5 bulan. Bibit tersebut kemudian ditanam pada medium tanah steril. Sterilisasi tanah dilakukan dengan uap panas selama 3-4 jam.

Medium yang digunakan berupa campuran tanah steril dan kompos dengan perbandingan 1:1 yang diberikan sesuai perlakuan yang telah ditentukan. Kompos dan 
tanah steril dihomogenkan dan dimasukkan kedalam polibag berkapasitas $1 \mathrm{~kg}$.

Inokulum JMA yang digunakan adalah jenis Glomus sp, diperoleh dari Balai Besar Perbenihan dan Proteksi Tanaman Perkebunan (BBPPTP) Surabaya dengan merk dagang Glomofert ${ }^{\circledR}$ dengan formulasi berupa zeolit yang bercampur dengan spora, hifa, dan akar tanaman jagung yang terlah terkolonisasi JMA. Inokulasi JMA dilakukan bersamaan dengan penanaman bibit pada polybag, dicampur pada medium tanam yang sudah disiapkan sesuai perlakuan sebanyak $30 \mathrm{~g} /$ tanaman.

\section{Pengamatan}

\section{Intensitas penyakit}

Pengamatan dilakukan pada daun cengkeh di tanaman sampel yang sama untuk pengamatan yang lain. Perhitungan dilakukan dengan mengkategorikan serangan penyakit di setiap daun yang diamati, menggunakan kategori yang telah dimodifikasi pada Tabel 1 (Herwidyarti, 2011 dalam Herwidyarti, Ratih, \& Sembodo, 2013).

Tabel 1. Kategori serangan penyakit bercak daun

\begin{tabular}{cll}
\hline Skala & \multicolumn{1}{c}{ Kategori } & \multicolumn{1}{c}{ Gejala } \\
\hline 0 & Tanaman sehat & Tanaman sehat/ tidak ada serangan \\
1 & Sangat ringan & Bercak pada daun antara $>0 \%-10 \%$ \\
2 & Ringan & Bercak pada daun antara $>10 \%-20 \%$ \\
3 & Agak parah & Bercak pada daun antara $>20 \%-40 \%$ \\
4 & Parah & Bercak pada daun antara $>40 \%-60 \%$ \\
5 & Sangat parah & Bercak pada daun $>60 \%$ \\
\hline
\end{tabular}

Sumber: (Herwidyarti et al., 2013).

Hasil pengamatan yang diperoleh selanjutnya dimasukkan ke dalam rumus intensitas penyakit:

$$
I P=\frac{\sum(n \times v)}{(Z \times N)} \times 100 \%
$$

Keterangan:

IP : Intensitas Penyakit (\%)

$\mathrm{n} \quad$ : Jumlah daun yang terserang pada tiap kategori

$\mathrm{N}$ : Jumlah daun yang diamati

$\mathrm{Z}$ : Nilai numerik atau harga kategori serangan patogen

$\mathrm{v}$ : Nilai numerik atau harga setiap kategori serangan patogen

\section{Komponen pertumbuhan}

Komponen pertumbuhan yang diamati meliputi tinggi tanaman, jumlah daun, dan diameter batang. Pengukuran tinggi tanaman dan jumlah daun dimulai pada 14 hari setelah pemindahan bibit ke polibag, kemudian diulang setiap 2 minggu sampai minggu ke-20.

\section{Deteksi asam salisilat dengan metode Kromatografi Lapis Tipis (KLT)}

Sampel daun sebanyak $10 \mathrm{~g}$ dioven selama 4 hari pada suhu $50^{\circ} \mathrm{C}$. Setelah kering, daun dihaluskan hingga menjadi serbuk. Satu gram serbuk dilarutkan dalam $25 \mathrm{ml}$ etanol 95\%, selanjutnya larutan didiamkan selama 24 jam. Larutan disaring dan diuapkan, kemudian residu dilarutkan kembali dalam $1 \mathrm{ml}$ etanol.

Serbuk asam salisilat sebanyak $20 \mathrm{mg}$ dilarutkan dalam $10 \mathrm{ml}$ etanol, larutan tersebut digunakan sebagai larutan pembanding. Fase gerak (FG) yang digunakan adalah etil asetat : methanol : ammonia dengan perbandingan masing-masing sebanyak $8 \mathrm{ml}: 1,9 \mathrm{ml}: 0,1 \mathrm{ml}$. Kemudian FG dimasukkan ke dalam Chamber KLT. Sedangkan untuk fase diam (FD) menggunakan Silica gel 60 F254 yang telah ditetesi larutan strandard sebagai pembanding dan sampel yang akan diujikan. Hasil running dideteksi dengan sinar UV kemudian disemprot dengan $\mathrm{FeCl}_{3}$. Apabila posisi akhir dari tetesan 
ekstrak daun sama dengan posisi akhir larutan standard pembanding, maka hasilnya adalah positif. Masing-masing posisi akhir dari tetasan yang tampak dihitung nilai Rf-nya (Paar et al., 2008 dalam Fefirenta, 2014).

Nilai Rf diperoleh setelah pengembangan sampel yang menggambarkan perpindahan relatif sebuah komponen senyawa terhadap pelarut dan berhubungan dengan koefisien distribusi komponen, nilai Rf dapat dihitung dengan rumus sebagai berikut (Suswati et al., 2011) :

$$
R f=\frac{\text { Jarak perpindahan sampel }}{\text { Jarak perpindahan pelarut }}
$$

\section{E. Analisis data}

Data yang diperoleh kemudian dianalisis dengan sidik ragam (ANOVA), apabila terdapat pengaruh nyata dilanjutkan dengan uji Duncan Multiple Range Test (DMRT) pada taraf 5\% .

\section{HASIL DAN PEMBAHASAN}

\section{A. Pertumbuhan bibit cengkeh yang telah diinokulasi JMA}

Tidak ada interaksi antara pemberian JMA dengan kompos. Hal ini menunjukkan bahwa pemberian JMA dengan atau tanpa ditambah kompos mampu meningkatkan pertumbuhan bibit cengkeh, namun tidak berbeda nyata hasilnya ketika JMA dan kompos diberikan secara bersamaan. Tinggi bibit cengkeh yang diberi JMA lebih tinggi dibandingkan bibit yang tidak diberi JMA (Tabel 2).

Tabel 2. Pengaruh pemberian JMA, kompos, dan interaksinya terhadap tinggi tanaman (cm) cengkeh pada minggu ke-20 setelah inokulasi

\begin{tabular}{lccc}
\hline \multirow{2}{*}{ Mikoriza } & \multicolumn{3}{c}{ Bahan Organik } \\
\cline { 2 - 4 } $\mathrm{M}_{0}$ & $\mathrm{P}_{0}$ & $\mathrm{P}_{1}$ & Rata-rata \\
$\mathrm{M}_{1}$ & 22,10 & 21,57 & $21,83 \mathrm{a}$ \\
\hline Rerata & 23,53 & 24,18 & $23,85 \mathrm{~b}$ \\
\hline
\end{tabular}

Keterangan: Data yang diikuti huruf yang sama pada baris dan kolom sama tidak berbeda nyata menurut DMRT pada taraf kepercayaan 95\%. $\mathrm{M}_{0}$ (dengan JMA), $\mathrm{M}_{1}$ (tanpa JMA), $\mathrm{P}_{0}$ (tanpa kompos), $\mathrm{P}_{1}$ (dengan kompos). Tanda (-) menunjukkan tidak terdapat interaksi antara kedua faktor yang diuji.

Bibit cengkeh yang di inokulasi JMA tanpa kompos maupun dengan tambahan kompos memiliki tinggi tanaman lebih tinggi dibanding perlakuan tanpa inokulasi JMA. Penambahan kompos pada perlakuan yang dikombinasikan dengan JMA memiliki tinggi $24,18 \mathrm{~cm}$ pada minggu ke-20 atau lebih tinggi dibanding perlakuan lainnya.

Menurut Baas, Vandijk, dan Troelstra (1989) tanaman Plantago major L ssp Pleiosperma (daun sendok) dan kacang tanah (Lana, 2009) yang diberi JMA memiliki kemampuan yang lebih unggul dalam menyerap unsur hara yang dibutuhkan oleh tanaman yang nantinya akan berpengaruh terhadap metabolisme tanaman. Adanya penyediaan hara yang lebih baik tersebut menyebabkan metabolisme sel tanaman berjalan lebih baik sehingga pertumbuhan tanaman selama fase vegetatif tidak mengalami hambatan. Hal serupa dikemukakan oleh Prasasti, Kristanti, dan Sri (2013), JMA yang menginfeksi akar tanaman akan menghasilkan jaringan hifa eksternal yang tumbuh secara ekspansif, sehingga meningkatkan kapasitas akar dalam penyerapan air dan unsur hara, terutama fosfat (P). Selain itu, JMA juga memacu pembentukan hormonhormon pertumbuhan tanaman, seperti sitokinin dan auksin yang berperan dalam pembelahan dan pemanjangan sel dan hal ini semakin mengoptimalkan pertumbuhan tinggi tanaman (Talaca, 2010). Pada tanaman yang telah 
terinfeksi JMA, P dapat diserap secara langsung di sekitar daerah perakaran melewati epidermis akar, rambut akar, dan melalui bantuan hifa eksternal JMA di tanah (Smith, Smith, \& Jakobsen, 2003).

Jumlah daun pada minggu ke-20 setelah pemindahan bibit di polibag tidak menunjukkan adanya interaksi antara inokulasi JMA dengan pemberian kompos, tetapi terdapat beda nyata antara faktor pemberian JMA pada perlakuan diinokulasi JMA $\left(\mathrm{M}_{1}\right)$ dengan perlakuan tidak diinokulasi JMA ( $\left.\mathrm{M}_{0}\right)$ (Tabel 3).

Tabel 3. Pengaruh pemberian JMA, kompos, dan interaksinya terhadap jumlah daun cengkeh pada minggu ke20 setelah inokulasi

\begin{tabular}{lccc}
\hline \multirow{2}{*}{ Mikoriza } & \multicolumn{3}{c}{ Bahan Organik } \\
\cline { 2 - 4 } & $\mathrm{P}_{0}$ & $\mathrm{P}_{1}$ & Rata-rata \\
\hline $\mathrm{M}_{0}$ & 21.30 & 22.15 & $21.72 \mathrm{a}$ \\
$\mathrm{M}_{1}$ & 23.85 & 24.20 & $24.02 \mathrm{~b}$ \\
\hline Rerata & $22.57 \mathrm{a}$ & $23.17 \mathrm{a}$ & $(-)$ \\
\hline
\end{tabular}

Keterangan: Data yang diikuti huruf yang sama pada baris dan kolom sama tidak berbeda nyata menurut DMRT pada taraf kepercayaan 95\%. $\mathrm{M}_{0}$ (dengan JMA), $\mathrm{M}_{1}$ (tanpa JMA), $\mathrm{P}_{0}$ (tanpa kompos), $\mathrm{P}_{1}$ (dengan kompos). Tanda (-) menunjukkan tidak terdapat interaksi antara kedua faktor yang diuji. Data telah mengalami transformasi.

Berdasarkan Tabel 3 dapat diketahui bahwa rerata jumlah daun bibit cengkeh yang diberi JMA pada perlakuan diinokulasi JMA $\left(\mathrm{M}_{1}\right)$ secara statistik memberi pengaruh nyata terhadap jumlah daun dibandingkan perlakuan yang tidak diinokulasi JMA $\left(\mathrm{M}_{0}\right)$. Hal ini sejalan dengan pertumbuhan tinggi tanaman, pemberian JMA unggul pada bibit cengkeh mampu meningkatkan penyerapan air dan hara, sehingga meningkatkan hasil asimilat yang nantinya digunakan dalam pembentukan daun. Hal ini menunjukkan bahwa JMA yang diberikan membantu dalam meningkatkan pertumbuhan tanaman. Aplikasi JMA mampu memperbaiki status nutrisi tanaman, sehingga fotosintat dari tanaman yang diinokulasi JMA lebih optimal (Swastiningrum, 2015).

\section{B. Pengaruh inokulasi JMA terhadap intensitas penyakit}

Penyakit yang diteliti yaitu penyakit yang sering muncul dan mengganggu pertumbuhan bibit cengkeh. Gejala penyakit yang sering muncul berupa bercak pada daun tua yang dimulai dari tepian daun, kemudian menyebar keseluruh bagian daun. Daun menjadi kering kecoklatan, bagian yang terserang mengering dan tulang-tulang daunnya tampak terang, kemudian rontok pada gejala lebih lanjut, dan menurut (Semangun, 2000), penyakit tersebut adalah penyakit bercak daun yang disebabkan oleh jamur Colletotrichum gloeosporioides.

Pemberian JMA pada bibit cengkeh dapat meningkatkan ketahanan tanaman terhadap penyakit yang muncul selama penelitian. $C$. gloeosporioides merupakan patogen lemah yang hanya akan berkembang dan menimbulkan penyakit parah apabila tanaman inang dalam kondisi lemah. Namun, apabila tanaman yang diinfeksi adalah tanaman dengan kesehatan yang baik, maka intensitas penyakit bercak daun karena C. gloeosporioides akan rendah (Sariasih et al., 2012). Mekanisme perlindungan oleh JMA yang membuat tanaman lebih tahan terhadap penyakit karena terjadi (1) perbaikan status nutrien inangnya; (2) adanya pesaing bagi patogen untuk memperoleh fotosintat dan situs infeksi; (3) perubahan anatomi dan morfologi akar, dan (4) pengaktifan mekanisme pertahanan inang (Sylvia \& Chellami, 2001 dalam Rozy, Liestiany, \& Maftuhah, 2004).

Tabel 4 menunjukkan tidak ada interaksi antara inokulasi JMA dan pemberian kompos pada intensitas penyakit. Intensitas penyakit pada minggu ke-20 setelah pemindahan bibit di 
polibag menunjukkan bahwa intensitas penyakit bibit cengkeh yang diinokulasi JMA $\left(\mathrm{M}_{1}\right)$ berbeda nyata lebih rendah dibandingkan dengan bibit tanpa diberi JMA $\left(\mathrm{M}_{0}\right)$. Perkembangan intensitas penyakit mulai terlihat pada minggu ke-4 dan semakin meningkat hingga minggu ke20 (Gambar 1).

Tabel 4. Pengaruh pemberian JMA, kompos, dan interaksinya terhadap intensitas penyakit bercak daun cengkeh pada minggu ke-20 setelah pemindahan bibit di polibag

\begin{tabular}{lccc}
\hline \multirow{2}{*}{ Mikoriza } & \multicolumn{3}{c}{ Bahan Organik } \\
\cline { 2 - 4 } & $\mathrm{P}_{0}$ & $\mathrm{P}_{1}$ & Rata-rata \\
\hline $\mathrm{M}_{0}$ & 23.47 & 24.72 & $24.09 \mathrm{a}$ \\
$\mathrm{M}_{1}$ & 19.90 & 20.81 & $20.35 \mathrm{~b}$ \\
\hline Rata-rata & $21.68 \mathrm{a}$ & $22.76 \mathrm{a}$ & $(-)$ \\
\hline
\end{tabular}

Keterangan: Data yang diikuti huruf yang sama pada baris dan kolom sama tidak berbeda nyata menurut DMRT pada taraf kepercayaan 95\%. $\mathrm{M}_{0}$ (dengan JMA), $\mathrm{M}_{1}$ (tanpa JMA), $\mathrm{P}_{0}$ (tanpa kompos), $\mathrm{P}_{1}$ (dengan kompos). Tanda (-) menunjukkan tidak terdapat interaksi antara kedua faktor yang diuji.

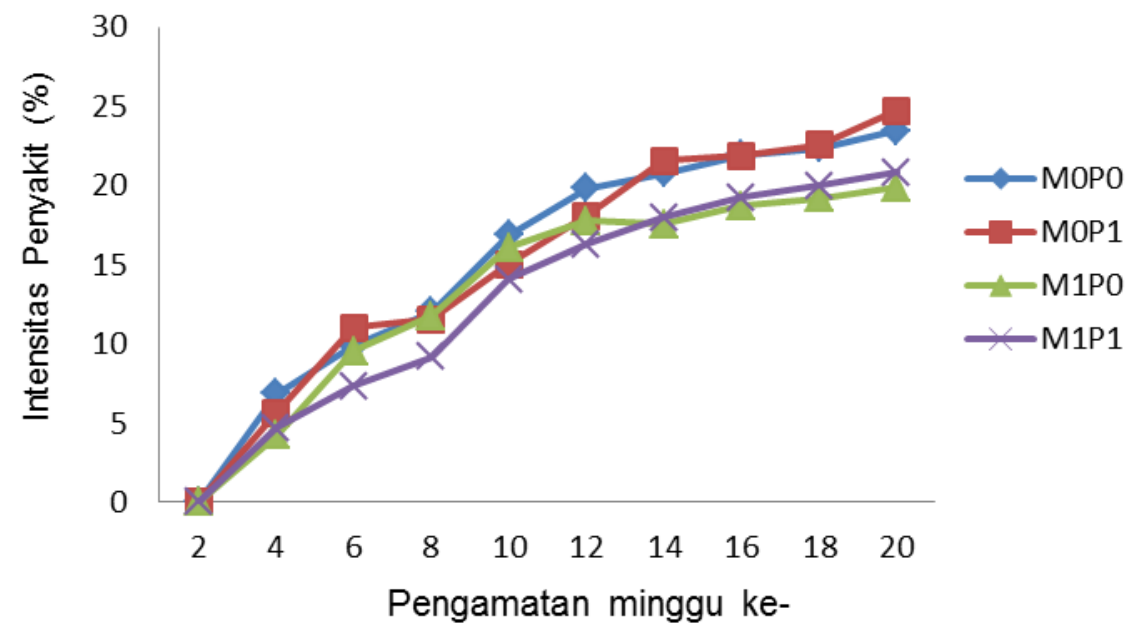

Keterangan: $\quad \mathrm{M}_{0} \mathrm{P}_{0}$ (tanaman tidak diinokulasi jamur mikoriza dan tidak diberi kompos), $\mathrm{M}_{0} \mathrm{P}_{1}$ (tanaman tanpa diinokulasi jamur mikoriza dengan pemberian kompos), $\mathrm{M}_{1} \mathrm{P}_{0}$ (tanaman yang diinokulasi jamur mikoriza tanpa pemberian kompos), dan $\mathrm{M}_{1} \mathrm{P}_{1}$ (tanaman yang diinokulasi jamur mikoriza dengan pemberian kompos).

Gambar 1. Intensitas penyakit bercak daun cengkeh

Pertumbuhan vegetatif bibit cengkeh selama penelitian secara tidak langsung dipengaruhi oleh keberadaan JMA yang diinokulasi dan patogen yang muncul selama pembibitan. Berdasarkan pengamatan penyakit selama 20 minggu setelah pemindahan bibit di polibag diketahui bahwa persentase intensitas penyakit bercak daun pada tiap perlakuan berkisar antara $19,90 \%$ sampai $24,72 \%$. Selama periode pembibitan intensitas penyakit bercak daun masuk pada kategori agak ringan sampai ringan. Inokulasi JMA pada bibit cengkeh $\left(\mathrm{M}_{1}\right)$ memiliki persentase intensitas penyakit terendah yaitu 20,35\% dibandingkan dengan perlakuan tanpa inokulasi JMA $\left(\mathrm{M}_{0}\right)$ yang mencapai $24,09 \%$.

Menurut Gottstein dan Kuć (1989) senyawa fosfat dapat meningkatkan aktivitas gen-gen ketahanan tanaman terhadap serangan patogen Colletotrichum sp dengan meningkatkan aktivitas enzim kitinase dan $\beta-1,3$ glukanase. JMA sendiri mampu meningkatkan kandungan 
senyawa fenol (zat antibiotik) pada tanaman, seperti flavonoid, isoflavonoid, dan tanin. Menurut Shaul et al., (2001) meningkatnya kandungan flavonoid pada tanaman tidak secara langsung berperan dalam ketahanan, tetapi berfungsi untuk mensintesis kitinase dan enzim Phenylalanine Ammonium Lyase (PAL). Aktivitas enzim Phenylalanine Ammonium Lyase (PAL), chalcone synthase (CHS), dan chalcone isomerase (CHI) juga dipicu oleh peningkatan aktivitas peroksidase, kitinase dan 1,3 glukanase diawal infeksi JMA pada tanaman (Blilou, Bueno, Ocampo, \& Garcia-Garrido, 2000). Enzim Phenylalanine Ammonium Lyase (PAL) berfungsi dalam menginduksi ketahanan terhadap serangan patogen (Prasasti et al., 2013; Volpin, Elkind, Okon, \& Kapulnik, 1994). Fenol sendiri akan dihasilkan oleh tanaman dengan segera jika tanaman tersebut diinfeksi oleh patogen dan diakumulasi pada daerah yang terinfeksi patogen (Agrios, 2005).

\section{Pengaruh inokulasi JMA terhadap asam salisilat}

Pada penelitian ini, analisis kuantitatif asam salisilat dilakukan dengan cara mengukur bercak secara langsung pada lempeng dengan menggunakan ukuran luas. Penetesan sampel sebesar $10 \mu \mathrm{l}$ dan $5 \mu \mathrm{l}$ untuk larutan baku sebagai pembanding. Hasil analisis KLT menunjukkan bahwa semua contoh yang dicoba memiliki kandungan asam salisilat berdasarkan hasil penotolan contoh yang kesemuanya hampir sejajar dengan larutan baku (Gambar 2).

Dari perbandingan nilai Rf antara contoh dan larutan baku asam salisilat yang diteteskan terlihat bahwa nilai $\mathrm{Rf}$ dari masing-masing contoh adalah $\mathrm{Rf}$ contoh $\mathrm{M}_{0} \mathrm{P}_{0} 0,60 \mathrm{~cm}, \mathrm{Rf}$ contoh $\mathrm{M}_{0} \mathrm{P}_{1}$ 0,61, Rf contoh $\mathrm{M}_{1} \mathrm{P}_{0}$ 0,61, Rf contoh $\mathrm{M}_{1} \mathrm{P}_{1}$ 0,62, mendekati nilai $\mathrm{Rf}$ asam salisilat yaitu $0,63 \mathrm{~cm}$, sehingga berdasarkan analisa KLT, semua contoh daun cengkeh dari 4 perlakuan yang dicoba diperkirakan mengandung asam salisilat.

Asam salisilat merupakan salah satu sinyal transduksi yang berakhir dengan systemic acquired resistance (SAR) serta menginduksi pembentukan pathogenesis related (PR) protein dan meningkatkan ketahanan tanaman terhadap infeksi patogen (Chen et al., 2010; Pieterse \& van Loon, 1999; Vlot, Dempsey, \& Klessig, 2009). Menurut hasil penelitian Pozo, Verhage, García-Andrade, García, dan Azcón-Aguilar (2009) menunjukkan bahwa simbiosis JMA dengan akar tanaman mampu mengaktivasi ketahanan tanaman baik secara lokal maupun sistemik. Salah satu tahanan ketahanan yang ditunjukkan oleh tanaman adalah terbentuknya senyawa fenol seperti asam salisilat yang merupakan senyawa yang dibentuk oleh tanaman ketika terjadi infeksi untuk mengaktivasi gengen ketahanan tanaman dalam menghadapi serangan patogen (Vidhyasekaran, 1997).

Akumulasi asam salisilat pada minggu ke20 setelah pemindahan bibit di polibag menunjukkan bahwa baik bibit cengkeh yang diinokulasi JMA maupun yang tidak diinokulasi JMA tetap menghasilkan asa m salisilat. Hasil tersebut diduga karena bibit telah terinfeksi patogen dalam waktu yang lama, sehingga tidak ada perbedaan dari tiap perlakuan. Hal tersebut sesuai dengan Widiastuti, Yoshino, Hasegawa, Nitta, dan Sato (2013), akumulasi asam salisilat terlihat meningkat 96 jam setelah perlakuan heat shock pada tanaman melon, dan akan mengalami penurunan 24 jam setelahnya. Penurunan kadar asam salisilat diduga karena adanya sintesis zat lain dari patogen yang mampu menekan pembentukan asam salisilat. Pembentukan asam absisat yang dipicu oleh patogen dapat menghambat proses SAR dan pembentukan asam salisilat pada tanaman (Yasuda et al., 2008 dalam Widiastuti et al., 2013). 


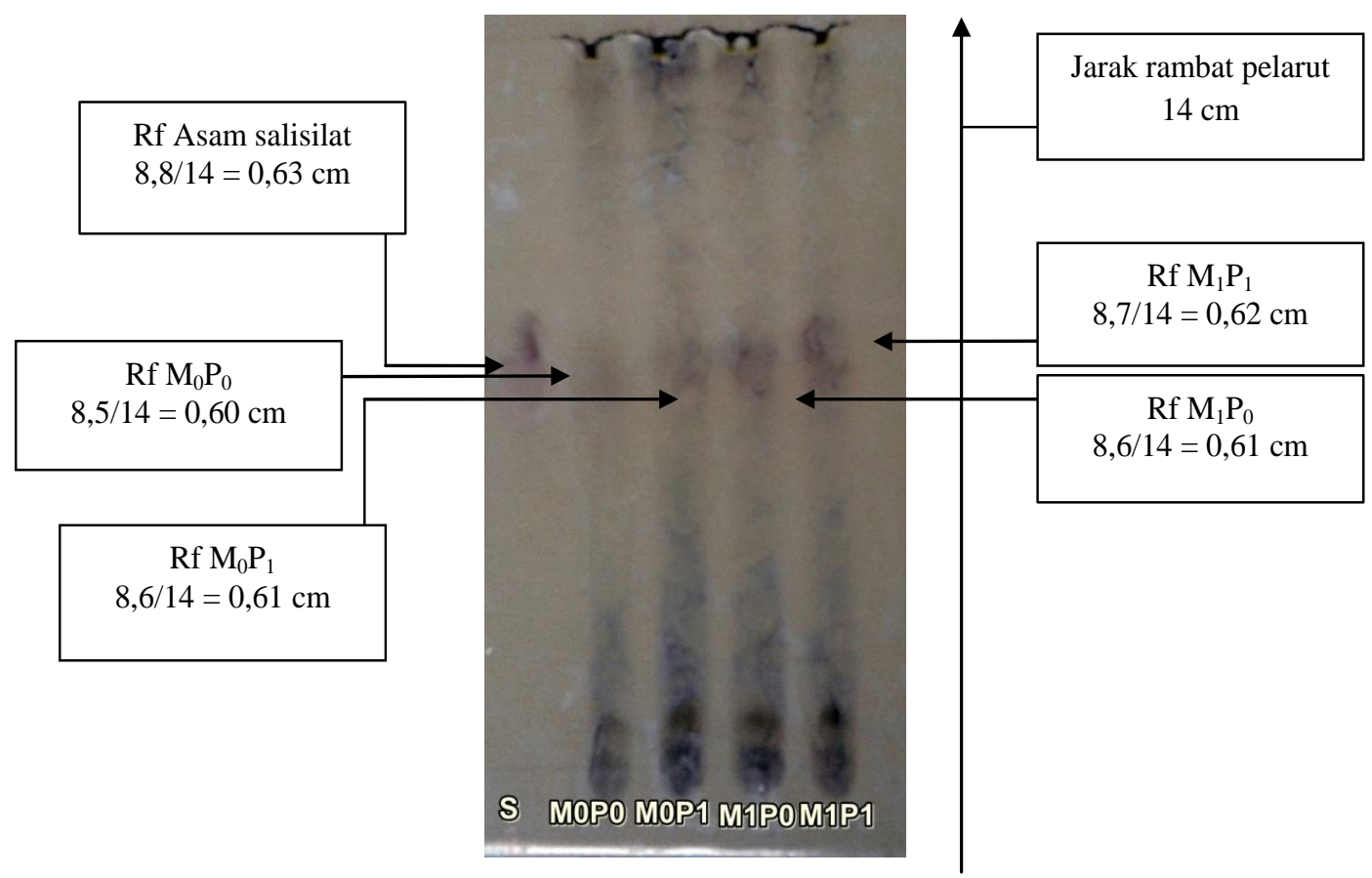

Keterangan: $\mathrm{S}$ (larutan baku asam salisilat), $\mathrm{M}_{0} \mathrm{P}_{0}$ (tanaman tidak diinokulasi jamur mikoriza dan tidak diberi kompos), $\mathrm{M}_{0} \mathrm{P}_{1}$ (tanaman tanpa diinokulasi jamur mikoriza dengan pemberian kompos), $\mathrm{M}_{1} \mathrm{P}_{0}$ (tanaman yang diinokulasi jamur mikoriza tanpa pemberian kompos), dan $\mathrm{M}_{1} \mathrm{P}_{1}$ (tanaman yang diinokulasi jamur mikoriza dengan pemberian kompos).

Gambar 2. Analisis asam salisilat dengan KLT

\section{KESIMPULAN}

Berdasarkan uraian dan pembahasan dapat disimpulkan bahwa pemberian JMA pada bibit cengkeh memiliki tinggi tanaman lebih tinggi, jumlah daun yang lebih banyak, serta memiliki intensitas penyakit bercak daun yang lebih rendah dibandingkan perlakuan tanpa inokulasi JMA. Selain itu, diketahui bahwa asam salisilat yang merupakan salah satu sinyal pertahanan tanaman terhadap penyakit yang akan aktif setelah infeksi patogen terdeteksi pada semua perlakuan.

\section{UCAPAN TERIMAKASIH}

Ucapan terimakasih disampaikan kepada Balai Besar Perbenihan dan Proteksi Tanaman Perkebunan (BBPPTP) Surabaya, dan Laboratorium Mikrobiologi, Fakultas Pertanian, Universitas Gadjah Mada yang telah banyak membantu selama penelitian

\section{DAFTAR PUSTAKA}

Agrios, G. N. (2005). Plant Pathology (5th ed). San Diego, USA: Elseviere Academic Press. https://doi.org/https://doi.org/10.1016/B9780-08-047378-9.50004-X

Aguzaen, H. (2009). Respon Pertumbuhan Bibit Stek Lada (Piper nisrum L.) Terhadap Pemberian Air Kelapa dan Berbagai Jenis CMA. Jurnal Agronobis, 1(1), 36-47.

Baas, R., Vandijk, C., \& Troelstra, S. R. (1989). Effects of Rhizosphere Soil, VesicularArbuscular Mycorrhizal Fungi and Phosphate on Plantago-major L. ssp pleiosperma Pilger. Plant and Soil, 113(1), 59-67. https://doi.org/10.1007/BF02181922

Balai Besar Litbang Sumberdaya Lahan Pertanian. (2006). Pupuk Organik Dan Pupuk Hayati. (R. D. M. Simanungkalit, D. A. Suriadikarta, R. Saraswati, D. Setyorini, \& W. Hartatik, Eds.). Bogor, Jawa Barat: Balai BesarLitbang Sumberdaya Lahan Pertanian.

Blilou, I., Bueno, P., Ocampo, J. A., \& GarciaGarrido, J. M. (2000). Induction of catalase and ascorbate peroxidase activities in tobacco roots inoculated with the arbuscular 
mycorrhizal Glomus mosseae. Mycological Research, 104(6), 722-725.

Chen, H., Zhang, Z., Teng, K., Lai, J., Zhang, Y., Huang, Y., ... Xie, Q. (2010). Up-regulation of LSB1/GDU3 affects geminivirus infection by activating the salicylic acid pathway. Plant Journal, 62(1), 12-23.

Direktorat Jenderal Perkebunan. (2016). Statistik Perkebunan Indonesia 2015-2017: Cengkeh. (D. D. Hendaryati \& Y. Arianto, Eds.). Sekretariat Direktorat Jenderal Perkebunan, Direktorat Jenderal Perkebunan, Kementerian Pertanian. Retrieved 4 Maret 2016 from http://ditjenbun.pertanian.go.id/tinymcpuk/ga mbar/file/statistik/2017/Cengkeh-15-17.pdf

Dirjenbun. (2012). Peningkatan produksi, produktivitas dan mutu tanaman rempah dan penyegar. Direktorat Jendral Perkebunan Kementerian Pertanian.

Fefirenta, A. (2014). Mekanisme Ketahanan Kakao Bermikoriza Terhadap Cekaman Kekeringan dan Gangguan Penyakit. Universitas Gadjah Mada, Yogyakarta.

Gottstein, H. D., \& Kuć, J. A. (1989). Induction of Systemic Resistance to Anthracnose in Cucumber by Phosphates. Phytopathology, 79, 176-179.

Hasid, R., \& Halim. (2011). Respon Bibit Tanaman Lada Terhadap Aplikasi Mikoriza Indigenous Gulma. JURNAL AGROTEKNOS, 1(1), 4447.

Herwidyarti, K. H., Ratih, S., \& Sembodo, D. R. J. (2013). Keparahan penyakit antraknosa pada cabai (Capsicum annum L.) Dan Berbagai Jenis Gulma. Jurnal Agrotek Tropika, 1(1), 102-106.

Lana, W. (2009). Pengaruh Dosis Pupuk Kandang Sapi dan Mikoriza Terhadap Pertumbuhan dan Hasil Tanaman Kacang Tanah (Arachis hypogaea L.) di Lahan Kering. Majalah Ilmiah Universitas Tabanan, 6(1).

Muis, A., Indradewa, D., \& Widada, J. (2013). Pengaruh Inokulasi Mikoriza Arbuskula Terhadap Pertumbuhan dan Hasil Kedelai (Glycine $\max (\mathrm{L}$.$) Merrill) pada Berbagai$ Interval Penyiraman. Vegetalika, 2(2), 7-20.

Pieterse, C. M. J., \& van Loon, L. C. (1999). Salicylic acid-independent plant defence pathways. Trends in Plant Science, 4(2), 52-58. https://doi.org/10.1016/S13601385(98)01364-8

Pozo, M. J., Verhage, A., García-Andrade, J., García, J. M., \& Azcón-Aguilar, C. (2009). Priming plant defence against pathogens by arbuscular mycorrhizal fungi. In Mycorrhizas Functional Processes and Ecological Impact (pp. 123-135). Verlag, Berlin, Heidelberg: Springer. https://doi.org/10.1007/978-3-54087978-7_9

Prasasti, O. H., Kristanti, I. P., \& Sri, N. (2013). Pengaruh Mikoriza Glomus fasciculatum Terhadap Pertumbuhan Vegetatif Tanaman Kacang Tanah yang terinfeksi Sclerotium rolfsii. Jurnal Sains Dan Seni POMITS, 2(2), 2337-3520.

Rozy, F., Liestiany, E., \& Maftuhah. (2004). Kemampuan Mikoriza Mengendalikan Serangan Rhizoctonia solani Kuhn Pada Kedelai. Jurnal Agroscientiae, 2(11), 91-98.

Sariasih, Y., Hadisutrisno, B., Pengajar, S., Pertanian, F., Bengkulu, U., Besar, G., ... Mada, U. G. (2012). Pengaruh Fungi Mikoriza Arbuskular Dalam Medium Zeolit Terhadap Pertumbuhan dan Intensitas Penyakit Bercak Daun Pada Bibit Kakao. Jurnal Agrotek Tropika, 1(1), 17.

Semangun, H. (2000). Penyakit-penyakit tanaman perkebunan di Indonesia. Yogyakarta: Gadjah Mada University Press.

Shofiana, R. H., Sulistyowati, L., \& Muhibuddin, A. (2015). Eksplorasi Jamur Endofit dan Khamir pada Tanaman Cengkeh (Syzygium aromaticum) Serta Uji Potensi Antagonismenya terhadap Jamur Akar Putih (Rigidoporus microporus). Jurnal HPT, 3(1), 75-83.

Smith, S. E., Smith, F. A., \& Jakobsen, I. (2003). Mycorrhizal Fungi Can Dominate Phosphate Supply to Plants Irrespective of Growth Responses. Plant Physiology, 133(1), 16-20. https://doi.org/10.1104/pp.103.024380

Suharti, N., Habazar, T., Nasir, N., Dachryanus, \& Jamsari. (2011). Induksi Ketahanan Tanaman Jahe Terhadap Penyakit Layu Ralstonia solanacearum Ras 4 Menggunakan Fungi Mikoriza Arbuskular (FMA) Indigenus. Jurnal HPT Tropika, 11(1), 102-111.

Suswati, Habazar, T., Husin, E. F., Nasir, N., Putra, D. P., \& Taylor, P. (2011). Senyawa Phenolik Akar Pisang CV . Kepok (Musa acuminata) yang Diinduksi dengan Fungi Mikoriza Arbuskular Indigenus PU10-Glomus sp 1 terhadap Penyakit Darah Bakteri. Jurnal Natur Indonesia, 13(65), 207-213.

Swastiningrum, A. (2015). Mekanisme Jamur Mikoriza arbuskular dalam menekan perkembangan penyakit pada bibit tebu. Universitas Gadjah Mada. 
Talaca, H. (2010). Status Cendawan Mikoriza Vesikular Arbuskular (MVA) Pada Tanaman. In Prosiding Seminar Pekan Serealia Nasional.

Vidhyasekaran, P. (1997). Fungal Pathogenesis in Plants and Crops: Molecular Biology and Host Defense Mechanisms. New York: Marcel Dekker Inc.

Vlot, A. C., Dempsey, D. A., \& Klessig, D. F. (2009). Salicylic Acid, a Multifaceted Hormone to Combat Disease. Annual Review of Phytopathology,47(1),177-206.

https://doi.org/10.1146/annurev.phyto.05090 8.135202
Volpin, H., Elkind, Y., Okon, Y., \& Kapulnik, Y. (1994). A Vesicular Arbuscular Mycorrhizal Fungus (Glomus intraradix) lnduces a Defense Response in Alfalfa Roots. Plant Physiology, 104, 683-689.

Widiastuti, A., Yoshino, M., Hasegawa, M., Nitta, Y., \& Sato, T. (2013). Heat shock-induced resistance increases chitinase-1 gene expression and stimulates salicylic acid production in melon (Cucumis melo L.). Physiological and Molecular Plant Pathology.

https://doi.org/10.1016/j.pmpp.2013.01.003 